\title{
'Fixed Charge' Chemical Derivatization and Data Dependant Multistage Tandem Mass Spectrometry for Mapping Protein Surface Residue Accessibility
}

\author{
Xiao Zhou, ${ }^{\text {a }}$ Yali Lu, ${ }^{\text {a }}$ Wenjing Wang, ${ }^{\text {a }}$ Babak Borhan, ${ }^{\text {a }}$ and \\ Gavin E. Reid ${ }^{a, b}$ \\ a Department of Chemistry, Michigan State University, East Lansing, Michigan, USA \\ ${ }^{b}$ Department of Biochemistry and Molecular Biology, Michigan State University, East Lansing, Michigan, USA
}

Protein surface accessible residues play an important role in protein folding, protein-protein interactions and protein-ligand binding. However, a common problem associated with the use of selective chemical labeling methods for mapping protein solvent accessible residues is that when a complicated peptide mixture resulting from a large protein or protein complex is analyzed, the modified peptides may be difficult to identify and characterize amongst the largely unmodified peptide population (i.e., the 'needle in a haystack' problem). To address this challenge, we describe here the development of a strategy involving the synthesis and application of a novel 'fixed charge' sulfonium ion containing lysine-specific protein modification reagent, S, $\mathrm{S}^{\prime}$-dimethylthiobutanoylhydroxysuccinimide ester (DMBNHS), coupled with capillary HPLC-ESI-MS, automated CID-MS/MS, and data-dependant neutral loss mode MS $^{3}$ in an ion trap mass spectrometer, to map the surface accessible lysine residues in a small model protein, cellular retinoic acid binding protein II (CRABP II). After reaction with different reagent:protein ratios and digestion with Glu-C, modified peptides are selectively identified and the number of modifications within each peptide are determined by CID-MS/MS, via the exclusive neutral loss(es) of dimethylsulfide, independently of the amino acid composition and precursor ion charge state (i.e., proton mobility) of the peptide. The observation of these characteristic neutral losses are then used to automatically 'trigger' the acquisition of an $\mathrm{MS}^{3}$ spectrum to allow the peptide sequence and the site(s) of modification to be characterized. Using this approach, the experimentally determined relative solvent accessibilities of the lysine residues were found to show good agreement with the known solution structure of CRABP II. (J Am Soc Mass Spectrom 2010, 21, 1339-1351) @ 2010 American Society for Mass Spectrometry

$\mathrm{M}$ ass spectrometry (MS) combined with protein labeling has found increasing utility as an alternative tool to conventional high-resolution methods such as X-ray crystallography or NMR for the examination of higher order protein structure (e.g., tertiary and quaternary), conformation, ligand binding, and dynamics [1]. Although typically providing lower resolution than these more established approaches, MS-based analysis strategies have particular advantages in sensitivity and speed, and the capability of analyzing proteins or protein complexes that are not amenable to crystallization, or that fall outside the mass range routinely accessible by NMR.

A variety of MS/protein labeling methods have been developed, and are based on either the use of (1) hydrogen-deuterium exchange (HDX) [2,3] or (2) stable chemical modification [4-6], before proteolytic diges-

Address reprint requests to Dr. G. E. Reid, Department of Chemistry, Michigan State University, 229 Chemistry Building, East Lansing, MI 48842, USA. E-mail: reid@chemistry.msu.edu tion and analysis by HPLC-MS and/or tandem mass spectrometry (MS/MS). HDX may potentially be used to probe the entire protein backbone, thereby providing the highest resolution of the MS-based approaches. However, limitations of HDX that can hamper determination of the precise location of exchange sites and therefore limit the spatial resolution that can be obtained, are the back-exchange of deuterium to hydrogen during proteolysis and sample handling before MS analysis [7, 8], and hydrogen/deuterium 'scrambling' during CID-MS/MS analysis [9]. Recently, the latter problem has been largely overcome by the use of alternate dissociation techniques such as electron capture dissociation (ECD) [10] and electron-transfer dissociation (ETD) during MS/MS [11].

Stable chemical labeling strategies have included (1) nonspecific oxidative modification of protein side-chain functional groups induced by hydroxyl radicals formed via the radiolysis of water by synchrotron $\mathrm{X}$-ray pulses [4], or by photolysis of $\mathrm{H}_{2} \mathrm{O}_{2}$ using pulsed UV lasers [5], and (2) specific labeling [6] or cross-linking [12] of 
selected amino acid side-chain functional groups within a protein of interest. For both approaches, the reactivity of individual amino acid side chains within the protein of interest is highly dependent on their degree of exposure (i.e., 'accessibility') to the solvent environment. Protein solvent accessible amino acid residues have significant biological importance, since they are often intimately involved in protein folding and in protein-protein or protein-ligand interactions. Thus, the use of these methods can provide detailed information for de novo protein structure analysis, or provide constraints to structural modeling efforts directed toward proteins not amenable to X-ray crystallography or NMR

A particular advantage of oxidative radical labeling approaches is that the reaction typically occurs in a time scale faster than that for protein unfolding, thereby allowing the dynamics of protein conformational changes to be examined [4]. It has been demonstrated that all 20 amino acids plus cystine can be oxidized by hydroxyl radicals, potentially providing high spatial resolution. However, the resultant mass spectra may be complicated and difficult to interpret due to the wide variety of oxidative products that can be formed [13]. Hydroxyl radical reactions may also lead to cleavage of peptide bonds, cleavage or ring opening of amino acid side chains, or the formation of protein cross-links. Moreover, when the oxidation sites are distributed randomly among several surface amino acid residues, the concentration of each oxidized peptide may be too low to detect [14]. There is also a concern that extensive oxidation may alter a protein's native conformation, thereby leading to erroneous results [15-17].

Despite the potential loss of spatial resolution, chemical labeling methods that specifically target a particular functional group or amino acid side chain have some advantages over nonspecific labeling methods in terms of the accessibility of the chemical reagents (i.e., access to pulsed X-ray or UV laser sources is not required), the ability to use protein "friendly" conditions during the modification process, and the simplicity of the resultant mass spectra [4]. Lysine is one of the most widely targeted amino acids for chemical modification because it is usually located at protein surfaces due to the presence of its positively charged polar side chain under physiological $\mathrm{pH}$ conditions. Consequently, lysine residues are often involved in protein-protein or protein-ligand interactions [18-22]. Acetic anhydride was the earliest lysine derivatization reagent used [18]. More recently, however, lysine targeted labeling strategies have shifted towards the use of N-hydroxysuccinimide (NHS) esters, due to their improved reaction specificity and a roughly 1000-fold lower required concentration compared with acetic anhydride [22-26]. Lysine-specific modification by S-methylthioacetimidate has also been recently reported [27]. The resultant amidine has a positive charge at physiological $\mathrm{pH}$, a feature that mimics the native lysine side chain and therefore may serve to minimize labeling induced alter- ations in protein conformation. The positive charge also increases the ionization efficiency of modified peptides, thereby improving the sensitivity and sequence coverage obtainable by mass spectrometry. Despite the demonstrated benefits of these specific chemical labeling methods for mapping protein solvent accessible residues, a common problem is that when a complicated peptide mixture resulting from a large protein or protein complex is analyzed, the modified peptides may be difficult to detect amongst the largely unmodified peptide population, i.e., constituting a 'needle in a haystack' problem.

To overcome this problem, we have developed a chemical derivatization and multistage MS/MS $\left(\mathrm{MS}^{n}\right)$ based analysis strategy, involving the introduction of a 'fixed-charge' sulfonium ion to peptides or proteins containing certain structural features (e.g., the side chains of selected amino acids such as methionine [28-31], or cysteine [32], or within a cross-linking reagent targeting lysine residues [33]. CID-MS/MS of these peptide ions results in the exclusive loss of a dialkylsulfide moiety from the modified side chain under low-energy CID-MS/MS conditions, independently of the amino acid composition and precursor ion charge state (i.e., proton mobility) of the peptide [3437]. Therefore, derivatized peptides can be readily identified from within complex mixtures by using automated selective neutral loss or precursor ion scan mode MS/MS methods, without requirement for purification or otherwise enrichment before analysis. Based on the results obtained from previous studies of sulfonium ion derivatized peptide ions, an expected increase in selectivity and sensitivity of one to two orders of magnitude over conventional MS based approaches can be achieved, due to the reduction in chemical noise associated with the MS/MS experiment [28, 31]. Further structural interrogation of identified peptide ions is readily achieved by subjecting the characteristic MS/MS product ion to multistage MS/MS $\left(\mathrm{MS}^{3}\right.$ in a quadrupole ion trap mass spectrometer, or by energy resolved 'pseudo' $\mathrm{MS}^{3}$ in a triple quadrupole mass spectrometer). Furthermore, the incorporation of 'light' and 'heavy' isotopically encoded labels into the fixedcharge derivatives has also enabled the extension of this approach to the differential quantitative analysis of peptide abundances, via measurement of the relative abundances of the neutral loss product ions generated by dissociation of the light and heavy labeled peptide ions $[28,31]$.

Here, as an initial step toward extending this strategy toward the improved analysis of higher order protein structures, we describe the synthesis, characterization, and initial application of an amine-specific sulfonium ion containing protein modification reagent, S,S'-dimethylthiobutanoylhydroxysuccinimide ester [DMBNHS (1)] using a model protein, human cellular retinoic acid binding protein II (CRABP II) [38]. 


\section{Materials and Methods}

\section{Materials}

Sodium methanethiolate, $\gamma$-butyrolactone, tris (hydroxymethyl)aminomethane (Tris), and guanidine hydrochloride were purchased from Sigma-Aldrich (St. Louis, MO, USA). Anhydrous dimethyl sulfoxide (DMSO) (stored over $3 \AA$ sieves), N-hydroxysuccinimide (NHS) and $N, N^{\prime}$-dicyclohexylcarbodiimide (DCC) were from Fluka (Buchs, Switzerland). $\mathrm{HCl}$ and $\mathrm{NaCl}$ were purchased from Columbus Chemical Industries (Columbus, WI, USA). Diethyl ether, $\mathrm{KCl}$, Dimethylformamide (DMF), and Silica gel (200-425 mesh) were from Jade Scientific (Canton, MI, USA). Chloroform, dichloromethane (DCM), and ethyl acetate were from Mallinckrodt Chemicals (Phillipsburg, NJ, USA). Acetonitrile $\left(\mathrm{CH}_{3} \mathrm{CN}\right)$ and iodomethane were purchased from EMD Chemicals (San Diego, CA, USA). $\mathrm{Na}_{2} \mathrm{HPO}_{4} \cdot 7 \mathrm{H}_{2} \mathrm{O}$ and $\mathrm{KH}_{2} \mathrm{PO}_{4}$ were from Spectrum Chemical Mfg. (Gardena, CA, USA). Endoprotease Glu-C was purchased from Thermo Fisher Scientific (Waltham, MA, USA). All aqueous solutions were prepared using deionized water obtained from a Barnstead nanopure diamond purification system (Dubuque, IA, USA). CRABP II was supplied by Dr. Babak Borhan (Department of Chemistry, Michigan State University).

\section{Synthesis and Characterization of Protein Modification Reagent}

The synthesis of the amine-specific protein modification reagent, DMBNHS (1) was achieved via a three-step process as described below.

\section{Synthesis of Methylthiobutyric Acid (2)}

Based on the method of Williams et al. [39], sodium methanethiolate $(6.97 \mathrm{~g}, 99.5 \mathrm{mmol})$ and $\gamma$-butyrolactone (4.46 mL, $74.63 \mathrm{mmol}$ ) were dissolved in $90 \mathrm{~mL}$ of anhydrous DMSO, and then the solution was stirred under $\mathrm{N}_{2}$ atmosphere at room temperature for $6 \mathrm{~d} ; 166$ $\mathrm{mL}$ of $1 \mathrm{M} \mathrm{HCl}$ was added to the resulting slurry, and then the aqueous solution was extracted with $6 \times 104$ $\mathrm{mL}$ of diethyl ether. The solvent was evaporated under reduced pressure. The crude product was purified by silica gel column chromatography (100\% ethyl acetate) to give $5.97 \mathrm{~g}$ (yield $60 \%$ ) product as a colorless oil. ${ }^{1} \mathrm{H}$ NMR $\left(500 \mathrm{MHz}, \mathrm{CDCl}_{3}\right): \delta 1.90(\mathrm{~m}, 2 \mathrm{H}, J=7), 2.07(\mathrm{~s}$, $3 \mathrm{H}), 2.47(\mathrm{t}, 2 \mathrm{H}, J=7), 2.52(\mathrm{t}, 2 \mathrm{H}, J=7.5), 11.15(\mathrm{~s}, 1 \mathrm{H})$.

\section{Synthesis of Methylthiobutyric \\ Hydroxysuccinimide Ester (3)}

Under a $\mathrm{N}_{2}$ atmosphere, NHS ( $\left.3.80 \mathrm{~g}, 33 \mathrm{mmol}\right)$ and (2) $(4.02 \mathrm{~g}, 30 \mathrm{mmol})$ were dissolved in a mixture of $\mathrm{CHCl}_{3}$ $(60 \mathrm{~mL})$ and $\mathrm{CH}_{2} \mathrm{Cl}_{2}(30 \mathrm{~mL})$. The mixture was stirred for $5 \mathrm{~min}$ at room temperature. Then DCC $(6.80 \mathrm{~g}, 33$ mmol) was added and a precipitate formed immediately. The resulting suspension was stirred in $\mathrm{N}_{2}$ atmosphere for $24 \mathrm{~h}$. The mixture was then filtered and the filtrate was collected and concentrated under reduced pressure. Five $\mathrm{mL}$ of $\mathrm{CH}_{3} \mathrm{CN}$ was then added to the residue and the resulting precipitate was filtered out. The resultant solution was dried in vacuo, after which $6.08 \mathrm{~g}(88 \%)$ of product was obtained as a white solid. ${ }^{1} \mathrm{H}$ NMR $\left(500 \mathrm{MHz}, \mathrm{CDCl}_{3}\right): \delta 2.02(\mathrm{~m}, 2 \mathrm{H}, J=7.5), 2.09$ $(\mathrm{s}, 3 \mathrm{H}), 2.59(\mathrm{t}, 2 \mathrm{H}, J=7), 2.75(\mathrm{t}, 2 \mathrm{H}, J=7), 2.82(\mathrm{~s}, 4 \mathrm{H})$.

\section{Synthesis of DMBNHS Iodide (1)}

(3) $(0.231 \mathrm{~g}, 1 \mathrm{mmol})$ and iodomethane $(0.71 \mathrm{~g}, 5 \mathrm{mmol})$ were dissolved in $2 \mathrm{~mL}$ of $\mathrm{CH}_{3} \mathrm{CN}$ followed by stirring in the dark at room temperature for $2 \mathrm{~d}$. The resulting solution was then concentrated under reduced pressure. The resultant yellow solid was washed with $10 \mathrm{~mL}$ of DCM then dried in vacuo to give $0.28 \mathrm{~g}(76 \%)$ product as yellow crystals. The product was stored in the dark. ${ }^{1} \mathrm{H}$ NMR $\left(500 \mathrm{MHz}, \mathrm{CD}_{3} \mathrm{CN}\right): \delta 2.16(\mathrm{~m}, 2 \mathrm{H}, J=$ $7.5), 2.77(\mathrm{~s}, 4 \mathrm{H}), 2.81(\mathrm{~s}, 6 \mathrm{H}), 2.85(\mathrm{t}, 2 \mathrm{H}, J=7.5), 3.29(\mathrm{t}$, $3 \mathrm{H}, J=7.5)$. Mass spectrometric analysis was also performed to further confirm the structure and gasphase fragmentation behavior of DMBNHS (1).

\section{Characterization by NMR and MS}

${ }^{1} \mathrm{H}$ NMR spectra were performed on a Varian Innovo $500 \mathrm{MHz}$ instrument and recorded in parts per million (ppm) referenced to the solvent resonances $(\delta)$, with coupling constants $(J)$ in hertz $(\mathrm{Hz})$. MS analysis was performed on a Thermo Scientific model LCQ Deca 3D quadrupole ion trap (San Jose, CA, USA) equipped with nanospray ESI (nESI) as the ionization source. Samples $(\sim 20 \mu \mathrm{M})$ were introduced at a flow rate of $2 \mu \mathrm{L} \mathrm{min}{ }^{-1}$. The spray voltage was set at $2.5 \mathrm{kV}$ and the capillary temperature was maintained at $150^{\circ} \mathrm{C}$. CID-MS/MS experiments were performed using standard isolation and activation conditions. MS of singly charged DMBNHS (1) revealed a single ion at $\mathrm{m} / \mathrm{z} 246.0$ corresponding to [DMBNHS] $]^{+}$. CID-MS/MS of the [DMBNHS] $^{+}$ion gave rise to a dominant product ion at $m / z 184.0$ corresponding to the dominant neutral loss of $\mathrm{S}\left(\mathrm{CH}_{3}\right)_{2}$ (data not shown).

\section{Protein Modification}

CRABP II $(25 \mu \mathrm{g}, 1.60 \mathrm{nmol})$ was suspended in $100 \mu \mathrm{L}$ of PBS buffer (NaCl: $136.75 \mathrm{mM}, \mathrm{Na}_{2} \mathrm{HPO}_{4} \cdot 7 \mathrm{H}_{2} \mathrm{O}: 8.10$ $\left.\mathrm{mM}, \mathrm{KCl}: 2.68 \mathrm{mM}, \mathrm{KH}_{2} \mathrm{PO}_{4}: 1.47 \mathrm{mM}\right)$. One $\mu \mathrm{L}$ of DMBNHS solution dissolved in DMF with concentrations of $8.0 \mathrm{mM}$ (CRABP II : DMBNHS =1:5), $16 \mathrm{mM}$ (CRABP II : DMBNHS = 1:10), $32 \mathrm{mM}$ (CRABP II : DMBNHS $=1: 20), 80 \mathrm{mM}$ (CRABP II : DMBNHS = 1:50), and $160 \mathrm{mM}$ (CRABP II : DMBNHS = 1:100) were added and each of them was incubated at room temperature for $30 \mathrm{~min}$. The reaction was immediately quenched by addition of a 160-fold molar excess of Tris 
(100 mM, pH 8.26 at $25^{\circ} \mathrm{C}$ ) then concentrated to dryness by vacuum centrifugation. $25 \mu \mathrm{L}$ of PBS buffer containing $6 \mathrm{M}$ guanidine hydrochloride was then added and the protein was denatured at $37^{\circ} \mathrm{C}$ for $1 \mathrm{~h}$. Two hundred twenty-five $\mu \mathrm{L}$ of $\mathrm{ddH}_{2} \mathrm{O}$ was added to bring the final volume to $250 \mu \mathrm{L}$. Five $\mu \mathrm{L}$ of $0.25 \mu \mathrm{g} / \mu \mathrm{L}$ Glu-C solution [Glu-C:CRABP II $=1: 20(w t / w t)]$ was added and the reaction mixture was incubated at $31^{\circ} \mathrm{C}$ in a water bath overnight. The digestion was quenched by adding $3 \mu \mathrm{L}$ of formic acid and diluted 5-fold to 1.6 $\mathrm{pmol} / \mu \mathrm{L}$ with $3 \%$ acetic acid $/ 5 \% \mathrm{CH}_{3} \mathrm{CN}$ before HPLC-MS analysis.

\section{HPLC-ESI-MS, CID-MS/MS and $-M S^{3}$ for Protein Analysis}

LC-MS, -MS/MS, and -MS ${ }^{3}$ analyses were performed using a Thermo LTQ linear quadrupole ion trap mass spectrometer (Thermo, San Jose, CA, USA) equipped with an Advance nESI source and Paradigm MS4 capillary RP-HPLC system (Michrom Bioresources, Auburn, CA, USA). Analyses were performed using automated methods created by the Xcalibur software (Thermo, San Jose, CA, USA). Samples were injected from a Paradigm AS1 autosampler (Michrom Bioresources, Auburn, CA, USA) onto a $200 \mu \mathrm{m}$ i.d. $\times 50 \mathrm{~mm}$ fused silica column packed with Magic C18 (3 $\mu \mathrm{m}$; Michrom Bioresources, Auburn, CA, USA) at a flow rate of $2 \mu \mathrm{L} \mathrm{min}{ }^{-1}$. Peptides were eluted using a linear 45 min gradient from $95 \%$ solvent A $(0.1 \%$ formic acid in $\left.\mathrm{H}_{2} \mathrm{O}\right)$ to $50 \%$ Solvent $\mathrm{B}\left(0.1 \%\right.$ formic acid in $\left.\mathrm{CH}_{3} \mathrm{CN}\right)$. The ion transfer tube of the mass spectrometer was set at $180{ }^{\circ} \mathrm{C}$, and the spray voltage was maintained at 2.0 $\mathrm{kV}$. The activation time was maintained at $30 \mathrm{~ms}$ using an activation $q$ value of 0.25 . The isolation window was maintained at $2.0 \mathrm{~m} / \mathrm{z}$ while the normalized collision energy was set at 35. All spectra were recorded in centroid mode. The LTQ was operated in a datadependent constant neutral loss scan (DDCNL) mode by performing CID-MS/MS scans on the three most intense peaks from each MS scan, while simultaneously searching for the defined neutral losses (Table 1). Here, the neutral losses with $m / z$ variance of \pm 0.5 were set to account for single, double, triple and quadruple $\mathrm{S}\left(\mathrm{CH}_{3}\right)_{2}$ neutral losses from $\left[\mathrm{M}^{N+}+(\mathrm{m}-\mathrm{N}) \mathrm{H}\right]^{\mathrm{m}+}$ precursor ions, where $\mathrm{M}$ represents the peptide, $N$ represents the number of modifications, and $m$ represents the different observed charge states ranging from +2 to +5 . If the targeted neutral loss was detected and appeared above a predefined threshold abundance of $1.0 \times 10^{4}$ counts, CID-MS ${ }^{3}$ was automatically initiated to further fragment the most intense neutral loss product ion. Dynamic exclusion was enabled to analyze ions with the selected data dependent $m / z$ three times within $30 \mathrm{~s}$ before it was placed on a dynamic exclusion list for a period of $10 \mathrm{~s}$. Characterization of modification sites and peptide sequences were determined manually from interpretation of the $\mathrm{MS}^{3}$ spectra. The program GetArea [40] was used,
Table 1. Summary of the data dependant constant neutral loss (DDCNL) MS/MS values employed for the identification of DMBNHS modified Glu-C digest peptides from CRABP II

\begin{tabular}{ccl}
\hline $\begin{array}{c}\text { Neutral loss } \\
(\mathrm{m} / \mathrm{z})\end{array}$ & $\begin{array}{c}\text { Number of } \mathrm{S}\left(\mathrm{CH}_{3}\right)_{2} \\
\text { neutral losses }\end{array}$ & Precursor ion \\
\hline \hline 62.00 & 1 & {$\left[\mathrm{M}^{\mathrm{N}}\right]^{+a}$} \\
& 2 & {$\left[\mathrm{M}^{\mathrm{N}}+(2-\mathrm{N}) \mathrm{H}\right]^{2+a}$} \\
& 3 & {$\left[\mathrm{M}^{\mathrm{N}}+(3-\mathrm{N}) \mathrm{H}\right]^{3+a}$} \\
49.60 & 4 & {$\left[\mathrm{M}^{\mathrm{N}}+(4-\mathrm{N}) \mathrm{H}\right]^{4+} \mathrm{a}$} \\
46.50 & 4 & {$\left[\mathrm{M}^{\mathrm{N}}+(5-\mathrm{N}) \mathrm{H}\right]^{5+a}$} \\
41.33 & 3 & {$\left[\mathrm{M}^{\mathrm{N}}+(4-\mathrm{N}) \mathrm{H}\right]^{4+a}$} \\
37.20 & 2 & {$\left[\mathrm{M}^{\mathrm{N}}+(3-\mathrm{N}) \mathrm{H}\right]^{3+a}$} \\
31.00 & 3 & {$\left[\mathrm{M}^{\mathrm{N}}+(5-\mathrm{N}) \mathrm{H}\right]^{5+a}$} \\
& 1 & {$\left[\mathrm{M}^{\mathrm{N}}+(2-\mathrm{N}) \mathrm{H}\right]^{2+a}$} \\
24.80 & 2 & {$\left[\mathrm{M}^{\mathrm{N}}+(4-\mathrm{N}) \mathrm{H}\right]^{4+a}$} \\
20.67 & 2 & {$\left[\mathrm{M}^{\mathrm{N}}+(5-\mathrm{N}) \mathrm{H}\right]^{5+a}$} \\
15.50 & 1 & {$\left[\mathrm{M}^{\mathrm{N}}+(3-\mathrm{N}) \mathrm{H}\right]^{3+a}$} \\
12.40 & 1 & {$\left[\mathrm{M}^{\mathrm{N}}+(4-\mathrm{N}) \mathrm{H}\right]^{4+} \mathrm{a}$} \\
\hline
\end{tabular}

${ }^{\mathrm{a}} \mathrm{N}=$ number of modifications.

with all parameters set at the default values, to calculate the solvent-accessibilities of lysine amino acid side chains and the N-terminal amino group of CRABP II, based on the NMR solution structure of CRABP II.

\section{Computational Methods}

Model structures of the neutral and protonated sidechain functional groups of lysine (methylamine), histidine (4-methyl imidazole), and arginine (N-methyl guanidine), as well as the side chain formed via the loss of $\mathrm{S}\left(\mathrm{CH}_{3}\right)_{2}$ from the DMBNHS modified peptides ( $N$ methyl iminohydrofuran) were initially optimized at the PM3 semi-empirical level of theory to identify likely candidates for the global minimum, followed by further optimization at the B3LYP/6-311+G(d,p) level of theory [41]. Single point calculations were then performed at the MP2/6-311+G(2d,p) level of theory. All optimized structures were subjected to vibrational frequency analysis at the B3LYP/6-311+G(d,p) level. Proton affinities were calculated according to the negative of the enthalpy of the protonation reaction, as described previously [42].

\section{Results and Discussion}

\section{Design of the DMBNHS Protein Modification Reagent}

The DMBNHS (1) reagent was specifically designed to have favorable solution phase reactivity and gas-phase fragmentation characteristics for application in a multistage tandem mass spectrometry strategy for the 'targeted' identification and characterization of modified peptides, as described below and depicted in Scheme 1. First, it has an NHS-ester moiety which enables the reagent to react specifically in solution towards the $\varepsilon$-amino groups on lysine residue side chains and/or 


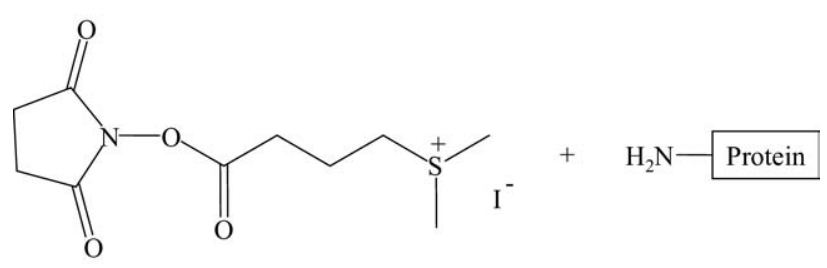

(1) DMBNHS iodide Glu-C Digestion HPLC, ESI-MS
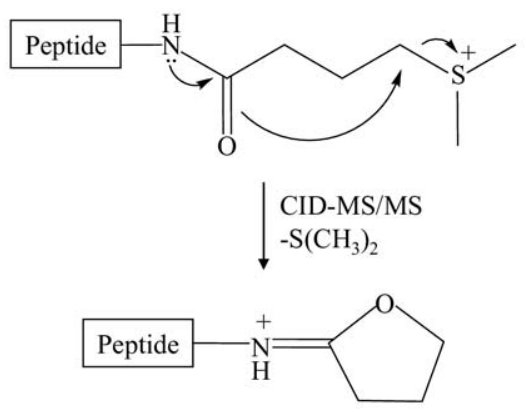

$\mathrm{CID}^{\mathrm{M}} \mathrm{MS}^{3}$

Scheme 1. Schematic of the solution phase DMBNHS (1) protein modification and gas-phase CID-MS/MS and -MS ${ }^{3}$ fragmentation reactions of DMBNHS modified peptide ions.

free $\mathrm{N}$-termini within the protein of interest. It also contains a sulfonium ion moiety, whose permanent charge potentially enhances the ionization efficiency [43], and which serves as an efficient leaving group to facilitate the thermodynamically favored exclusive neutral loss(es) of dimethylsulfide upon CID-MS/MS, independently of the amino acid composition and charge state of the precursor peptide ion (i.e., proton mobility), thereby allowing modified peptides to be readily identified from within a mixture of unmodified peptides, i.e., 'finding the needle in the haystack'. Furthermore, the number of neutral losses observed in the MS/MS spectrum is indicative of the number of modified residues within the peptide. The observation of the exclusive neutral loss(es) can be used to automatically 'trigger' the acquisition of an $\mathrm{MS}^{3}$ spectrum, in a data dependant mode of operation, to facilitate subsequent characterization of the peptide sequence and the site(s) of modification. Finally, the five-membered cyclic iminohydrofuran product that if formed via the loss of dimethylsulfide during MS/MS is stable to dissociation during subsequent CID-MS ${ }^{3}$, thereby allowing the peptide sequence and the site(s) of modification to be readily characterized.

CRABP II Modification by DMBNHS and HPLCESI-MS Analysis of the Resultant Glu-C Digest Peptides

The utility of the DMBNHS based protein modification and 'targeted' multistage tandem mass spectrometry strategy for the identification and characterization of modified peptides for mapping protein surface residue accessibilities was demonstrated here using a model protein, CRABP II. The complete sequence of CRABP II is shown in Scheme 2, with the 13 lysine residues distributed throughout the protein sequence and the $\mathrm{N}$-terminal residue labeled in bold text. The solventaccessibilities of these lysine amino acid side chains and the N-terminal amino group, based on the previously determined NMR solution structure of CRABP II [38], are predicted to range from $26.0 \%$ to $93.1 \%$ (Table 2 ) [40].

CRABP II was subjected to reaction with varying amounts of DMBNHS, with reagent/protein ratio's ranging from 5 to 100 . After $30 \mathrm{~min}$, the modification was quenched and the modified protein was digested overnight with Glu-C before being subjected to HPLCMS, -MS/MS, and - $\mathrm{MS}^{3}$ analysis. No reduction or subsequent alkylation was performed before protein digestion in the current study, as there are no disulfide bonds in the CRABP II protein sequence. However, we have demonstrated in preliminary studies that the sulfonium ion moieties contained within modified proteins are stable (i.e., not lost or degraded) under typical conditions employed for reduction of disulfide bonds using tris(2-carboxyethyl)phosphine (TCEP) (data not shown).

The base peak chromatograms obtained following LC-MS of each of the labeled CRABP II Glu-C digests are shown in Figure 1. The identities of the peaks in each chromatogram (determined following interpretation of the MS/MS and $\mathrm{MS}^{3}$ spectra obtained from each peak as discussed in detail below) are labeled in Figure 1 , and summarized in Table 2. The observed peptides represented $79 \%$ of the protein sequence and contained all 13 lysine residues and the $\mathrm{N}$-terminus. For each of the peptides, it can be seen that the extent of modification increases with increasing reagent to protein ratio, albeit to different extents depending on the identity of the peptide, indicating that each of the lysine residues are exposed on the surface of the protein, which is consistent with the known solution structure [38].

\section{CID-MS/MS and -MS Analysis of Peptides Formed by Glu-C Digestion of the DMBNHS Modified CRABP II Protein}

Following the acquisition of each MS scan, the three most abundant precursor ions were automatically sub-

${ }^{1}$ PNFSGNW ${ }^{8} \mathrm{KIIRSENFEELL}{ }^{20} \mathrm{KVLGVNVMLR}{ }^{30} \mathrm{KIAVAAAS}{ }^{38} \mathrm{KPAV}$ E ${ }^{44} \mathrm{KQEGDTFY} \mid{ }^{53} \mathrm{KTSTTVRTT} E \mathrm{~N} \mathrm{~F}^{66} \mathrm{KVG}$ EEFEEQTVDGRPC ${ }^{82} \mathrm{KSLV}$ ${ }^{86} \mathrm{KWESEN}{ }^{92} \mathrm{KMVCEQ}{ }^{98} \mathrm{KLL}^{101} \mathrm{KGEGP}{ }^{106} \mathrm{KTSWTRELTNDG}$ ELILTM TADDVVCTRVYVRE

Scheme 2. Amino acid sequence of cellular retinoic acid binding protein II (CRABP II). The DMBNHS modification sites are indicated in bold text, while the Glu-C digestion sites are indicated in italic text. 
Table 2. Summary of observed CRABP II Glu-C digest peptide sequences, retention time ranges, modifiable residues, and predicted amino acid solvent accessibilities

\begin{tabular}{|c|c|c|c|c|}
\hline $\begin{array}{l}\text { Peptide } \\
\text { residues }\end{array}$ & Sequence & $\begin{array}{l}\text { Retention time } \\
\text { range (min) }\end{array}$ & $\begin{array}{c}\text { Modifiable } \\
\text { residues present }\end{array}$ & $\begin{array}{l}\text { Predicted solvent } \\
\text { accessibilities }^{\text {a }}\end{array}$ \\
\hline \multirow[t]{3}{*}{$97-112$} & QKLLKGEGPKTSWTRE & $11.51-13.93$ & $\mathrm{~K}_{98}$ & 49.6 \\
\hline & & & $K_{101}$ & 72.7 \\
\hline & & & $\mathrm{K}_{106}$ & 42.6 \\
\hline $63-70$ & INFKVGEE & $14.49-15.46$ & $\mathrm{~K}_{66}$ & 60.5 \\
\hline $47-62$ & GDTFYIKTSTTVRTTE & $15.54-16.71$ & $K_{53}$ & 38.3 \\
\hline \multirow[t]{2}{*}{$1-13$} & PNFSGNWKIIRSE & $18.99-19.85$ & $\mathrm{P}_{1}$ & 57.8 \\
\hline & & & $\mathrm{K}_{8}$ & 45.7 \\
\hline $63-72$ & INFKVGEEFE & $20.06-21.10$ & $\mathrm{~K}_{66}$ & 60.5 \\
\hline \multirow[t]{2}{*}{$1-17$} & PNFSGNWKIIRSENFEE & $22.04-23.61$ & $\mathrm{P}_{1}$ & 57.8 \\
\hline & & & $\mathrm{K}_{8}^{1}$ & 45.7 \\
\hline \multirow[t]{4}{*}{$63-96$} & INFKVGEEFEEOTVDGRPCKSLVKWESENKMVCE & $23.94-25.20$ & $\mathrm{~K}_{66}^{\circ}$ & 60.5 \\
\hline & & & $\mathrm{K}_{82}$ & 28.1 \\
\hline & & & $\mathrm{K}_{86}$ & 56.2 \\
\hline & & & $\mathrm{K}_{92}$ & 26.0 \\
\hline \multirow[t]{3}{*}{$18-42$} & LLKVLGVNVMLRKIAVAAASKPAVE & $29.25-31.94$ & $\mathrm{~K}_{20}$ & 49.3 \\
\hline & & & $\mathrm{K}_{30}$ & 58.1 \\
\hline & & & $\mathrm{K}_{38}$ & 93.1 \\
\hline
\end{tabular}

a Solvent accessibilities were predicted based on the known solution phase structure of CRABP II [38], by using the GetArea program [40].

jected to CID-MS/MS. Following each MS/MS event, if product ions were observed at $\mathrm{m} / \mathrm{z}$ values corresponding to the neutral loss of one or more dimethylsulfide groups from a singly, doubly, triply or quadruply modified precursor ion with a charge state ranging from +1 to +5 (see Table 1), the most abundant of these product ions was automatically isolated and subjected to further dissociation by CID-MS ${ }^{3}$.

Figure 2 shows the CID-MS/MS and $-\mathrm{MS}^{3}$ spectra acquired from peptide 1-13 (PNFSGNWKIIRSE), which contains two modifiable residues, i.e., the secondary amino group of the N-terminal proline residue and the $\varepsilon$-amino of the lysine residue $\mathrm{K}_{8}$. Thus, it is expected that two singly modified peptides (i.e., $1-13^{1}$ (where the superscript number indicates the modified residue) and $1-13^{8}$, with the same mass but different modification sites), and one doubly modified peptide $\left(1-13^{(1,8)}\right.$ should be observed. Figure $2 a$ and $b$ show the product ion spectra obtained by CID-MS/MS of the triply charged $\left[1-13^{8}+2 \mathrm{H}\right]^{3+}$ and $\left[1-13^{1}+2 \mathrm{H}\right]^{3+}$ precursor ions from the peaks at approx. $19.8 \mathrm{~min}$ and $20.6 \mathrm{~min}$ in Figure 1. It can be seen that both these MS/MS spectra are identical, each giving rise to a single product ion via the exclusive loss of dimethylsulfide $\left(\mathrm{S}\left(\mathrm{CH}_{3}\right)_{2}\right)$. Similar results were obtained by dissociation of the doubly charged $\left(\left[1-13^{8}+\mathrm{H}\right]^{2+}\right.$ and $\left.\left[1-13^{1}+\mathrm{H}\right]^{2+}\right)$ precursor ions (shown in the insets to Figure 2a and b). Notably, the presence of a 'mobile' proton in the triply charged precursor ions (the doubly charged precursor ions are in a 'non-mobile' charge state) was observed to have no effect on the MS/MS fragmentation reaction involving the exclusive loss of $\mathrm{S}\left(\mathrm{CH}_{3}\right)_{2}$, consistent with previous studies demonstrating that the selective dissociation of sulfonium ion derivatized peptides occurs independently of the proton mobility of the precursor ion, i.e., that ionizing protons simply act as 'spectators' rather than participating in competing fragmentation reactions [28-33].

CID-MS ${ }^{3}$ of the $\left[1-13^{8}+2 \mathrm{H}-\mathrm{S}\left(\mathrm{CH}_{3}\right)_{2}\right]^{3+}$ and $\left[1-13^{1+}\right.$ $\left.2 \mathrm{H}-\mathrm{S}\left(\mathrm{CH}_{3}\right)_{2}\right]^{3+}$ product ions from Figure $2 \mathrm{a}$ and $\mathrm{b}$ gave rise to the spectra shown in Figure $2 \mathrm{c}$ and $\mathrm{d}$, respectively. Interpretation of the spectra in Figure $2 \mathrm{C}$ resulted in the assignment of a series of modified $\mathrm{y}_{6}{ }^{+2+}$, $\mathrm{y}_{7}{ }^{+2+}, \mathrm{y}_{8}{ }^{+2+}, \mathrm{y}_{9}{ }^{+2+}, \mathrm{y}_{10}{ }^{+2+}, \mathrm{y}_{11}{ }^{+2+}$, and $\mathrm{y}_{12}{ }^{+2+}$ and unmodified $\mathrm{y}_{4}, \mathrm{~b}_{2}$, and $\mathrm{b}_{3}$ product ions, where a dagger $\left({ }^{+}\right)$ indicates sequence ions containing one modified residue. These ions allowed the modification site to be located at the $\mathrm{K}_{8}$ residue. In contrast, Figure 2D contained a series of modified b-type product ions $\left(\mathrm{b}_{3}{ }^{\dagger}, \mathrm{b}_{5}{ }^{\dagger}\right.$, $\mathrm{b}_{6}{ }^{+}, \mathrm{b}_{7}{ }^{\dagger}, \mathrm{b}_{8}{ }^{+}, \mathrm{b}_{8}{ }^{+2+}, \mathrm{b}_{9}{ }^{+2+}, \mathrm{b}_{11}{ }^{+3+}$, and $\mathrm{b}_{12}{ }^{+3+}$ ) and a series of unmodified y-type ions, allowing the site of the modification to be localized to the $\mathrm{P}_{1}$ residue. CID-MS ${ }^{3}$ of the $\left[1-13^{8}+\mathrm{H}-\mathrm{S}\left(\mathrm{CH}_{3}\right)_{2}\right]^{2+}$ and $\left[1-13^{1}+\mathrm{H}-\mathrm{S}\left(\mathrm{CH}_{3}\right)_{2}\right]^{2+}$ product ions from the insets shown in Figure $2 \mathrm{a}$ and $\mathrm{b}$ resulted in the formation of a variety of $y$ - and b-type product ions, similar to those seen for the triply charged product ions in Figure 2c and d (data not shown). However, as the abundance of the doubly charged precursor ions were significantly lower than those for the triply charged precursors, the signal to noise for the $\mathrm{MS}^{3}$ spectra were substantially lower.

Figure $3 \mathrm{a}$ and $\mathrm{b}$ show the CID-MS/MS product ion spectra obtained from the doubly modified $\left(1-13^{1,8}\right.$ peptide, in its doubly (i.e., $\left[1-13^{1,8}\right]^{2+}$ ) and triply (i.e., $\left[1-13^{1,8}+\mathrm{H}\right]^{3+}$ ) charged precursor ion charge states, respectively. In each case, two characteristic neutral loss product ions were observed, corresponding to the neutral losses of one and two $\mathrm{S}\left(\mathrm{CH}_{3}\right)_{2}$ groups, indicative of the presence of two modifications within the peptide. Notably, for both spectra, product ions corresponding to the neutral loss of two $\mathrm{S}\left(\mathrm{CH}_{3}\right)_{2}$ groups were significantly more abundant than those corresponding to the 


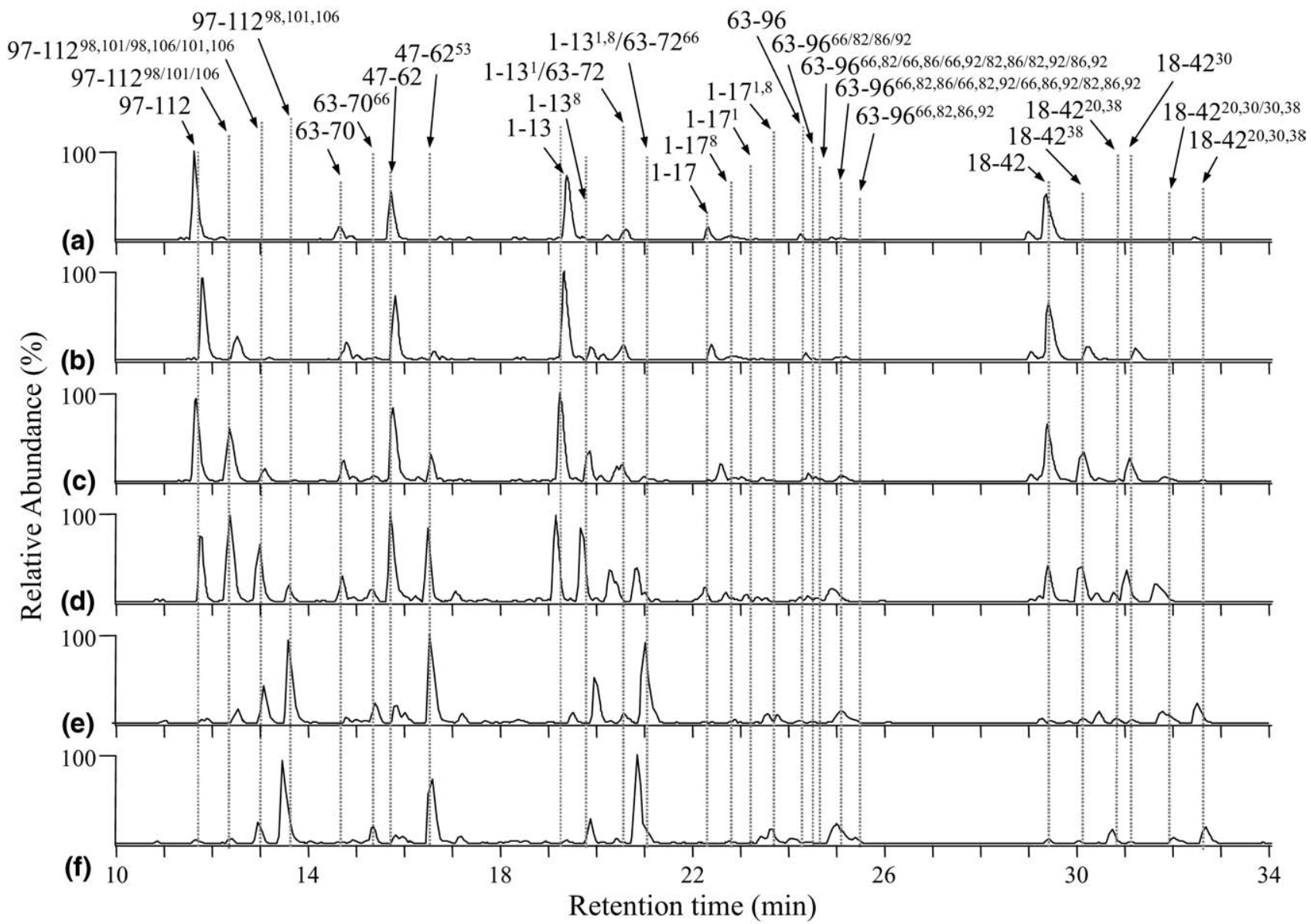

Figure 1. Base peak chromatograms of the Glu-C digests from (a) unmodified CRABP II and CRABP II modified with DMBNHS using (b) 5-fold, (c) 10-fold, (d) 20-fold, (e) 50-fold, and (f) 100-fold molar excess. Peaks are annotated as: $X-Y^{n}$, where the $X$ and $Y$ indicate the residue numbers within the protein, and the superscript $\mathrm{n}$ indicates the residue(s) that is modified. A superscript forward slash (/) indicates that isomeric forms of a given modified peptide were observed within a single co-eluting peak.

neutral loss of only one $\mathrm{S}\left(\mathrm{CH}_{3}\right)_{2}$ group. Thus, it was these product ions that were automatically selected for further dissociation by $\mathrm{MS}^{3}$. As shown in Figure $3 \mathrm{c}, \mathrm{MS}^{3}$ dissociation of the $\left[1-13^{1,8}-2 \mathrm{~S}\left(\mathrm{CH}_{3}\right)_{2}+\mathrm{H}\right]^{3+}$ product ion from Figure $3 \mathrm{~b}$ allowed the expected modification sites at the $\mathrm{P}_{1}$ and $\mathrm{K}_{8}$ residues to be readily assigned.

It is expected that the proton affinity of the iminohydrofuran containing functional group that is formed following the loss of $\mathrm{S}\left(\mathrm{CH}_{3}\right)_{2}$ from a DMBNHS sulfonium ion modified peptide would be higher than that of an unmodified amino group. If so, this could potentially result in a decreased 'proton mobility' within the MS/MS product ion, and could thereby limit the extent of sequence information that is obtained following $\mathrm{MS}^{3}$ for determination of the identity of the peptide and localization of the site of the modification, compared with that obtained from an unmodified peptide. Calculation of the proton affinity of the simplest model for the iminohydrofuran containing functional group (i.e., $\mathrm{N}$-methyl iminohydrofuran), at the MP2/6-311+ $\mathrm{G}(2 \mathrm{~d}, \mathrm{p}) / / \mathrm{B} 3 \mathrm{LYP} / 6-311+\mathrm{G}(\mathrm{d}, \mathrm{p})$ level of theory, resulted in a proton affinity of $228.2 \mathrm{kcal} \mathrm{mol}^{-1}$ (Supple- mental Table S1, which can be found in the electronic version of this article). This value is $17.2 \mathrm{kcal} \mathrm{mol}^{-1}$ higher than that calculated for the simplest model for lysine (methylamine, $211.0 \mathrm{kcal} \mathrm{mol}^{-1}$ ), and is intermediate between the calculated values for the simplest models for histidine (4-methyl imidazole, $223.5 \mathrm{kcal}$ $\mathrm{mol}^{-1}$ ) and arginine (N-methyl guanidine, $234.2 \mathrm{kcal}$ $\left.\mathrm{mol}^{-1}\right)$, at the same level of theory. Despite this result, a comparison of the $\mathrm{MS}^{3}$ product ion spectra obtained from the modified 1-13 peptide ions (e.g., the $\left[1-13^{8}-\right.$ $\left.\mathrm{S}\left(\mathrm{CH}_{3}\right)_{2}+2 \mathrm{H}\right]^{3+}$ and $\left[1-13^{1}-\mathrm{S}\left(\mathrm{CH}_{3}\right)_{2}+2 \mathrm{H}\right]^{3+}$ ions in Figure $2 \mathrm{c}$ and $\mathrm{d}$, and the $\left[1-13^{1,8}-2 \mathrm{~S}\left(\mathrm{CH}_{3}\right)_{2}+\mathrm{H}\right]^{3+}$ ion in Figure 3c, with the MS/MS spectra of the unmodified 1-13 peptide in the same charge state (i.e., the $[1-13+3 \mathrm{H}]^{3+}$ ion) (Supplementary Figure S1), revealed that the sequence coverage obtained following $\mathrm{MS}^{3}$ of the modified peptide ions was equivalent to, or greater than, that from the unmodified MS/MS spectrum. Interestingly, the $\mathrm{MS}^{3}$ spectrum obtained from the modified $\left[1-13^{8}-\mathrm{S}\left(\mathrm{CH}_{3}\right)_{2}+2 \mathrm{H}\right]^{3+}$ product ion $\left(\mathrm{K}_{8}\right.$ modified) was very similar to that obtained by MS/MS of the unmodified $[1-13+3 \mathrm{H}]^{3+}$ ion. This is consistent with the 


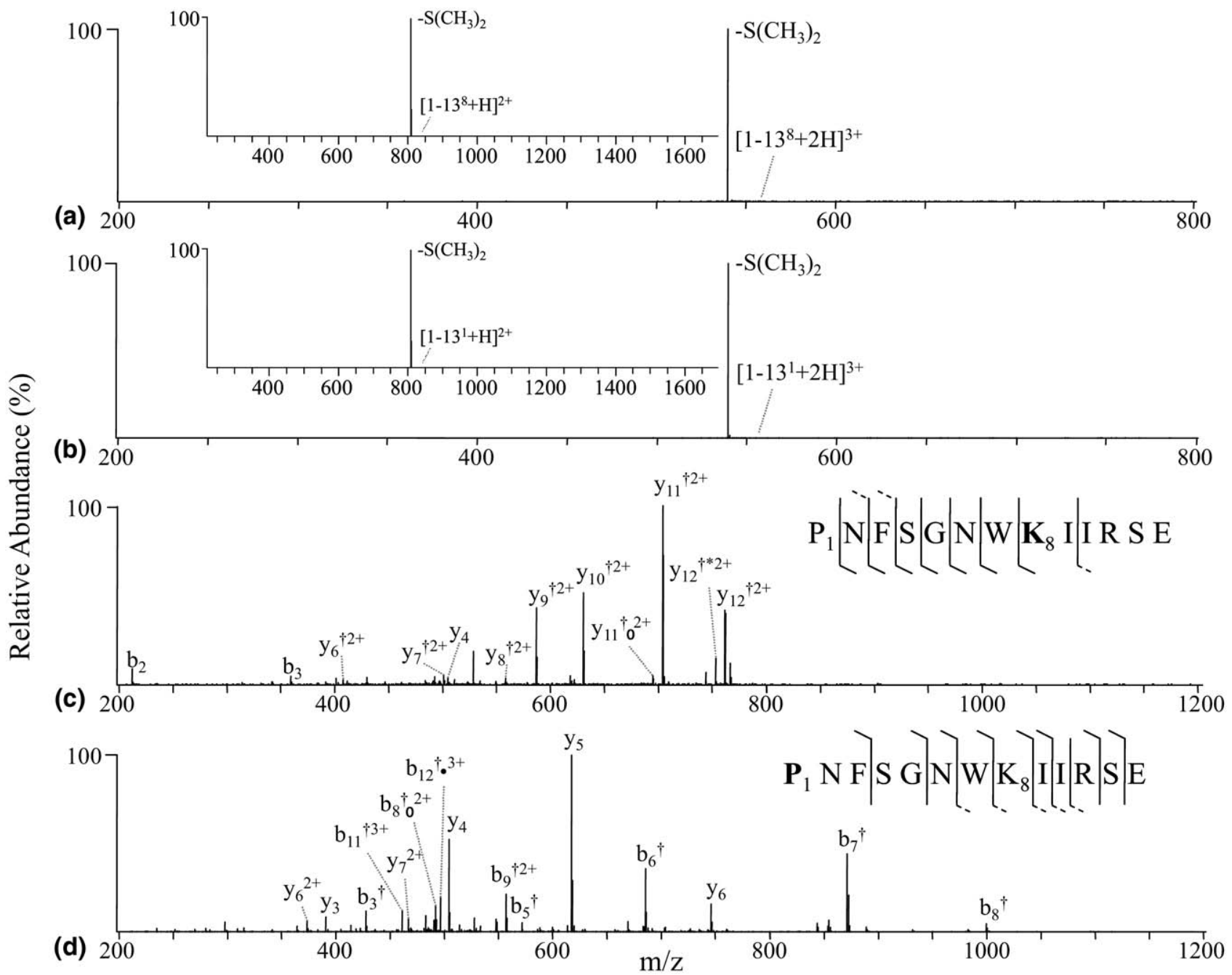

Figure 2. Multistage $\mathrm{MS}^{n}$ (CID-MS/MS and $-\mathrm{MS}^{3}$ ) of the isomeric DMBNHS singly modified CRABP II peptides PNFSGNWKIIRSE $\left(1-13^{8}\right)$ and PNFSGNWKIIRSE $\left(1-13^{1}\right)$. CID-MS/MS of the triply charged (a) $\left[1-13^{8}+2 \mathrm{H}\right]^{3+}$ and (b) $\left[1-13^{1}+2 \mathrm{H}\right]^{3+}$ precursor ions. The insets to (a) and (b) show the CID-MS/MS spectra from the doubly charged $\left[1-13^{8}+\mathrm{H}\right]^{2+}$ and $\left[1-13^{1}+\mathrm{H}\right]^{2+}$ precursor ions, respectively. CID-MS ${ }^{3}$ of $(\mathrm{C})$ the $\left[1-13^{8}+2 \mathrm{H}-\mathrm{S}\left(\mathrm{CH}_{3}\right)_{2}\right]^{3+}$ product ion from (a), and (d) the $\left[1-13^{1}+2 \mathrm{H}-\right.$ $\left.\mathrm{S}\left(\mathrm{CH}_{3}\right)_{2}\right]^{3+}$ product ion from (b). A superscript dagger $\left(^{+}\right)$indicates sequence ions containing one modified amino acid residue. A superscript asterisk indicates the loss of $\mathrm{NH}_{3}$. A superscript [open circle] indicates the loss of $\mathrm{H}_{2} \mathrm{O}$. A superscript dot $\left(^{\circ}\right)$ indicates the addition of $\mathrm{H}_{2} \mathrm{O}$. A dashed line indicates an unmodified sequence ion was observed. A solid line indicates a sequence ion was observed with one modified amino acid.

expected sites of proton localization in both peptides being at the arginine, lysine (or iminohydrofuran) and $\mathrm{N}$-terminal residues (considered to be 'non-mobile', 'partially mobile', and 'mobile', respectively). In contrast, the $\mathrm{MS}^{3}$ spectra from the modified $\left[1-13^{1}-\right.$ $\left.\mathrm{S}\left(\mathrm{CH}_{3}\right)_{2}+2 \mathrm{H}\right]^{3+}$ product ion ( $\mathrm{P}_{1}$ modified) and the $\left[1-13^{1,8}-2 \mathrm{~S}\left(\mathrm{CH}_{3}\right)_{2}+\mathrm{H}\right]^{3+}$ product ion $\left(\mathrm{P}_{1}\right.$ and $\mathrm{K}_{8}$ modified) were substantially different to the MS/MS spectrum from the unmodified peptide, presumably due to differences in the site(s) of protonation or the decreased proton mobility of the $\mathrm{N}$-terminal within these peptides (a protonated iminohydrofuran moiety located at the $\mathrm{N}$-terminal residue of the modified peptide would be expected to result in a 'partially mobile' rather than 'mobile' proton).
The results obtained following CID-MS/MS and $-\mathrm{MS}^{3}$ of the modified forms of peptide 18-42, (LLKVLGVNVMLRKIAVAAASKPAVE) containing three lysine residues (resulting in the potential formation of three singly modified peptides $\left(18-42^{20}, 18-42^{30}\right.$ and $18-42^{38}$, three doubly modified peptides $\left(18-42^{20,30}, 18\right.$ $42^{20,38}$ and $18-42^{30,38}$ and one triply modified peptide $\left(18-42^{20,30,38}\right)$, further demonstrates the utility of the sulfonium ion derivatization approach for the 'targeted' identification and characterization of modified peptide ions. As shown in Figure 1, two singly modified forms of the 18-42 peptide were observed. As expected, CIDMS/MS of the triply charged $\left[18-42^{38}+2 \mathrm{H}\right]^{3+}$ and [18$\left.42^{30}+2 \mathrm{H}\right]^{3+}$ precursor ions were identical, each giving rise to the exclusive neutral loss of a single $\mathrm{S}\left(\mathrm{CH}_{3}\right)_{2}$ 


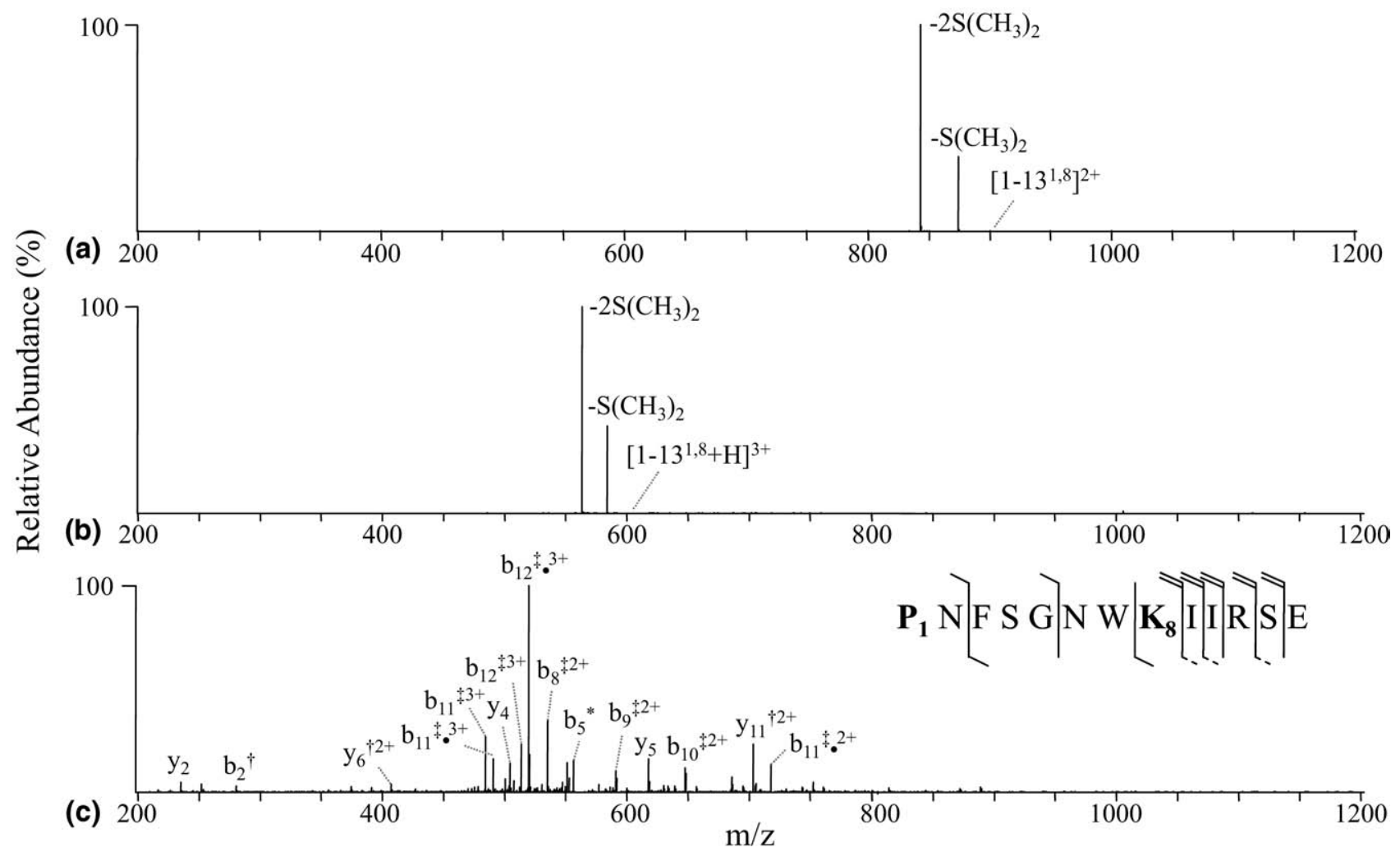

Figure 3. Multistage $\mathrm{MS}^{n}$ (CID-MS/MS and $-\mathrm{MS}^{3}$ ) of the DMBNHS doubly modified CRABP II peptide PNFSGNWKIIRSE (1-13 $\left.3^{1,8}\right)$. CID-MS/MS of (a) the doubly charged $\left(\left[1-13^{1,8}\right]^{2+}\right)$ and (b) triply charged $\left(\left[1-13^{1,8}+\mathrm{H}\right]^{3+}\right)$ precursor ions. CID-MS ${ }^{3}$ of $(\mathbf{c})$ the $\left[1-13^{1,8}+\mathrm{H}-2 \mathrm{~S}\left(\mathrm{CH}_{3}\right)_{2}\right]^{3+}$ product ion from (b). A superscript dagger $\left({ }^{+}\right)$indicates sequence ions containing one modified amino acid residue. A superscript double dagger $\left({ }^{\ddagger}\right)$ indicates sequence ions containing two modified amino acid residues. A superscript open circle indicates the loss of $\mathrm{H}_{2} \mathrm{O}$. A superscript $\left(^{\circ}\right)$ indicates the addition of $\mathrm{H}_{2} \mathrm{O}$. A dashed line indicates an unmodified sequence ion was observed. A single solid line indicates a sequence ion was observed with one modified amino acid. A double solid line indicates a sequence ion was observed with two modified amino acids.

group (data not shown). By analyzing the $\mathrm{MS}^{3}$ spectra obtained by dissociation of the $\left[18-42^{38}+2 \mathrm{H}-\mathrm{S}\left(\mathrm{CH}_{3}\right)_{2}\right]^{3+}$ and $\left[18-42^{30}+2 \mathrm{H}-\mathrm{S}\left(\mathrm{CH}_{3}\right)_{2}\right]^{3+}$ product ions, the modification sites were located on the $\mathrm{K}_{38}$ residue for the $18-42^{38}$ form of the peptide (Figure $4 \mathrm{a}$ ), and on the $\mathrm{K}_{30}$ residue for the $18-42^{30}$ form of the peptide (Figure $4 \mathrm{~b}$ ). No evidence was found for a form of the 18-42 peptide that was singly modified at the $\mathrm{K}_{20}$ residue, suggesting that this residue was less reactive to the DMBNHS reagent (i.e., less accessible) compared with the adjacent $\mathrm{K}_{30}$ and $\mathrm{K}_{38}$ residues (see the section below for further discussion).

CID-MS/MS of the quadruply charged precursor ions of the three doubly modified $18-42$ peptide ions (the $18-42{ }^{20,38}$ peak was separately resolved while the $18-42^{20,30}$ and $18-42^{30,38}$ peaks were closely eluting) each resulted in the exclusive loss of up to two $\mathrm{S}\left(\mathrm{CH}_{3}\right)_{2}$ groups, similar to that described above for the 1-13 peptide, indicating the presence of two modifications within the peptides (data not shown). Once again, the loss of two $\mathrm{S}\left(\mathrm{CH}_{3}\right)_{2}$ groups was the dominant fragmentation pathway. The $\mathrm{MS}^{3}$ spectra shown in Figure 5 were used to assign the sites of modification to the $\mathrm{K}_{20}$ and $K_{38}$ residues for the $18-42^{20,38}$ peptide (Figure 5a), the $K_{20}$ and $K_{30}$ residues for the $18-42^{20,30}$ peptide (Figure $5 b$ ), and the $K_{30}$ and $K_{38}$ residues for the $18-42^{30,38}$ peptide (Figure $5 \mathrm{c}$ ). Because the $18-42^{20,30}$ and $18-42^{30,38}$ peptides were not well resolved, several of the ions from the 18-42 20,30 peptide (e.g., $\mathrm{b}_{16}{ }^{\ddagger 2+}, \mathrm{b}_{17}{ }^{\ddagger 2+}$, and $\mathrm{b}_{18}{ }^{\ddagger 2+}$ ) were also observed in the spectrum from the $18-42^{30,38}$ peptide.

Finally, Supplemental Figure S2 shows the CIDMS/MS and -MS ${ }^{3}$ spectra of the quadruply charged precursor ion of the triply modified $18-42^{20,30,38}$ peptide. MS/MS resulted in the characteristic neutral loss of up to three $\mathrm{S}\left(\mathrm{CH}_{3}\right)_{2}$ groups, indicating the presence of three modifications within the peptide, while $\mathrm{MS}^{3}$ confirmed the identity of the peptide sequence and localization of the modifications on each of the three lysine residues, $\mathrm{K}_{20}, \mathrm{~K}_{30}$, and $\mathrm{K}_{38}$. For comparison of the sequence coverage obtained from each of the singly, doubly and triply modified forms of the 18-42 peptide ions, Supplemental Figure S3 shows the CID-MS/MS spectra from the triply and quadruply protonated precursor ions of the unmodified 18-42 peptide, while the results obtained by MS/MS or CID-MS ${ }^{3}$ of the unmodified and 


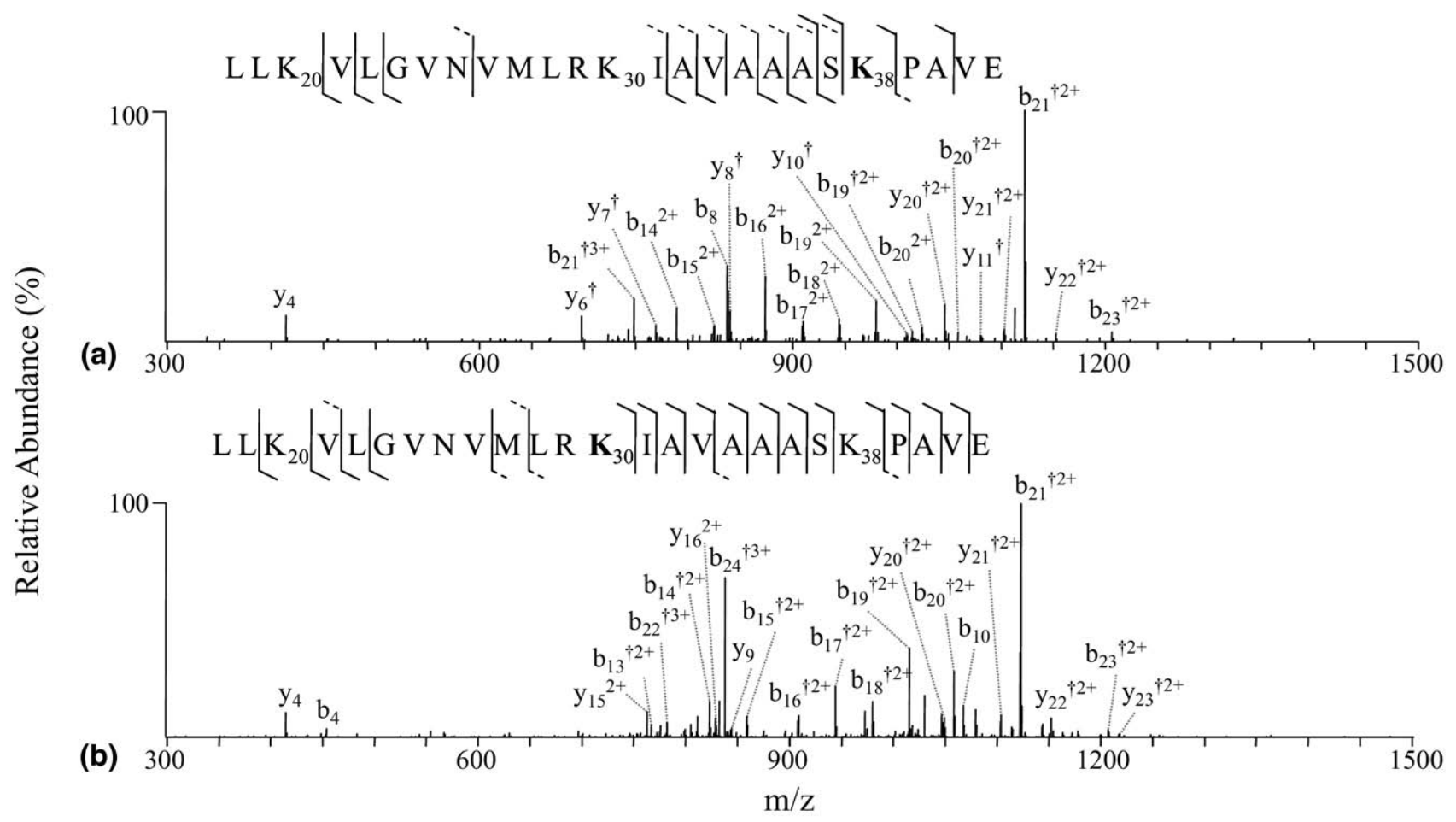

Figure 4. $\mathrm{CID}^{-\mathrm{MS}^{3}}$ of the triply charged product ions formed by CID-MS/MS of the isomeric DMBNHS singly modified CRABP II peptides LLKVLGVNVMLRKIAVAAASKPAVE $\left(18-42^{38}\right)$ and LLKVLGVNVMLRKIAVAAASKPAVE $\left(18-42^{30}\right)$. (a) CID-MS ${ }^{3}$ of the $\left[18-42^{38}+2 \mathrm{H}-\mathrm{S}\left(\mathrm{CH}_{3}\right)_{2}\right]^{3+}$ product ion. (b) $\mathrm{CID}-\mathrm{MS}^{3}$ of the $\left[18-42^{30}+2 \mathrm{H}-\mathrm{S}\left(\mathrm{CH}_{3}\right)_{2}\right]^{3+}$ product ion. A superscript dagger $\left(^{\dagger}\right)$ indicates sequence ions containing one modified amino acid residue. A dashed line indicates an unmodified sequence ion was observed. A single solid line indicates a sequence ion was observed with one modified amino acid.

modified forms, respectively, of the remaining peptides in Figure 1 (97-112, 63-70,63-72, 47-62, and 1-17) are shown in Supplemental Figures S4-S15.

\section{Correlation of the Modified Peptide Ion Abundances with the Predicted Solvent Accessibilities of CRABP II}

Normalized plots of the relative abundances (summed from all observed charge states) of the unmodified, singly modified, doubly modified, and triply modified peptides versus the stoichiometric ratios of DMBNHS reagent to protein are shown in Figure 6. These plots summarize the reactivity of the peptides towards DMBNHS and therefore are indicative of the solvent accessibility of these peptide regions. The experimentally determined solvent accessibilities of the lysine residues in these peptide regions were also compared with the calculated solvent accessibilities, determined using the GetArea program [40] (see Table 2) based on the known NMR solution phase structure of CRABP II. The results are discussed in detail below. Note that the plots shown herein were generated assuming that the ionization efficiency of a given peptide was not affected by the DMBNHS modification, even though potential enhancement of the ionization efficiencies caused by the incorporation of the sulfonium ion may occur [43]. Also, it was assumed that the magnitude of any enhancement in ionization efficiencies would be similar between peptides, and would therefore not have an impact on determination of the relative solvent accessibilities. Furthermore, the consistency of our results with the predicted solvent accessibilities of the CRABP II lysine residues (see below) suggest that any differences caused by ionization efficiency are not substantial.

Peptides 47-62 (Figure 6a) and 63-70 (Figure 6b) each contain only one lysine residue, $\mathrm{K}_{53}$ and $\mathrm{K}_{66}$, respectively. The peak relative abundance of the singly modified $63-70$ peptide $(64 \% \pm 1 \%)$ was higher than that of the $47-62$ peptide $(58 \% \pm 3 \%)$. These data suggest that $\mathrm{K}_{66}$ is more accessible to the DMBNHS reagent compared with $\mathrm{K}_{53}$. This result is consistent with the GetArea predicted solvent accessibilities of these residues $\left(60.5 \%\right.$ for $\mathrm{K}_{66}$ and $38.3 \%$ for $\left.\mathrm{K}_{53}\right)$.

Peptides 1-13 and 1-17 contain two identical modifiable residues, $\mathrm{P}_{1}$ (N-terminus) and $\mathrm{K}_{8}$, so their responses to an increasing amount of modification reagent were expected to be the same. However, 1-13 (Figure 6c) showed a higher extent of modification than 1-17 (Figure 6d). This might be due to a difference in the extent of ionization efficiency between the unmodified and modified forms between the two peptides, or a 


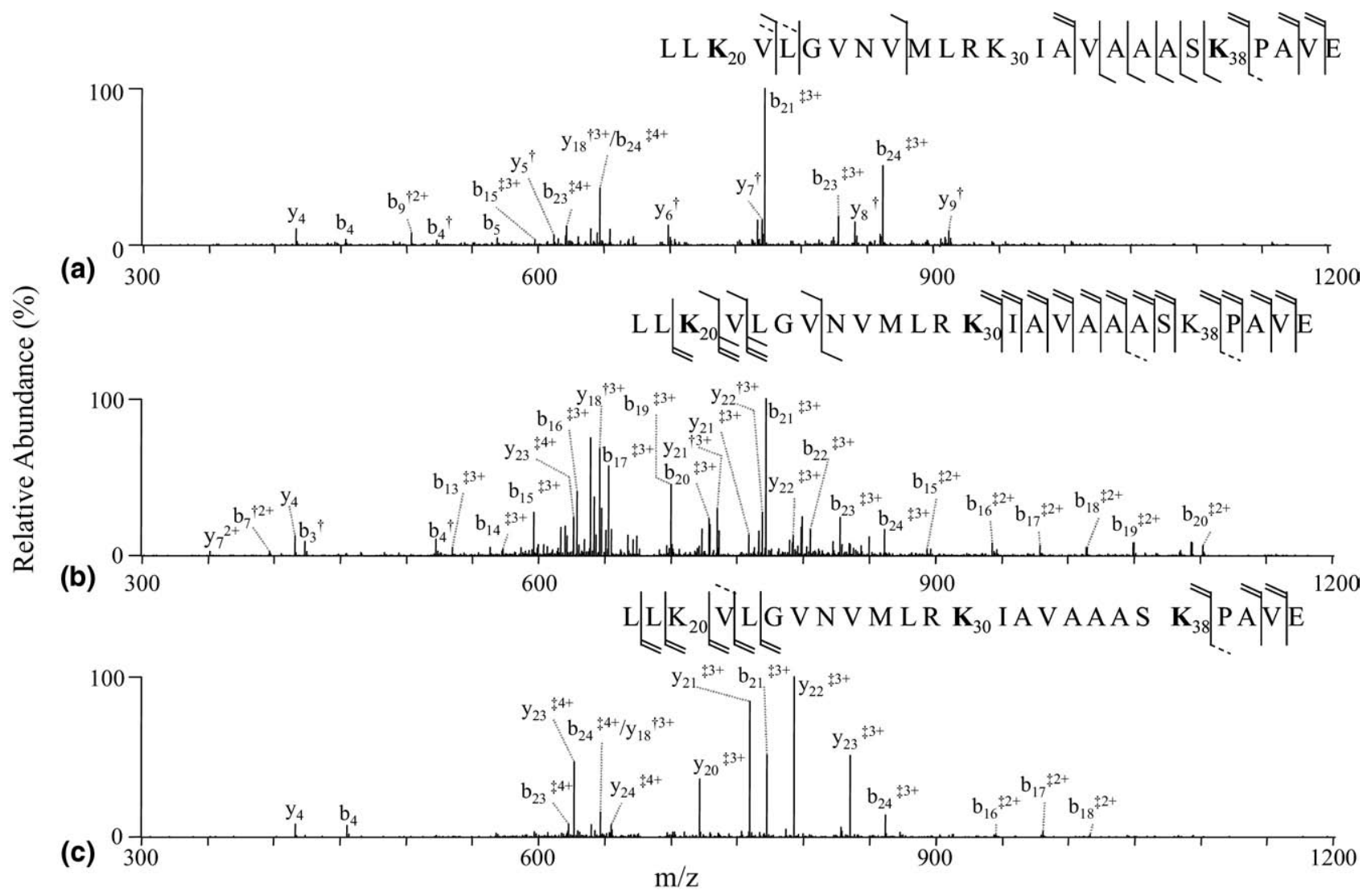

Figure 5. $\mathrm{CID}^{-\mathrm{MS}^{3}}$ of the quadruply charged product ions formed by CID-MS/MS of the isomeric DMBNHS doubly modified CRABP II peptides LLKVLGVNVMLRKIAVAAASKPAVE $\left(18-42^{20,38}\right)$, LLKVLGVNVMLRKIAVAAASKPAVE (18-42 ${ }^{20,30}$ ), and LLKVLGVNVMLRKIAVAAASKPAVE (18$\left.42^{30,38}\right)$. (a) $\mathrm{CID}^{-\mathrm{MS}^{3}}$ of the $\left[18-42^{20,38}+2 \mathrm{H}-2 \mathrm{~S}\left(\mathrm{CH}_{3}\right)_{2}\right]^{4+}$ product ion. (b) CID-MS ${ }^{3}$ of the [18$\left.42^{20,30}+2 \mathrm{H}-2 \mathrm{~S}\left(\mathrm{CH}_{3}\right)_{2}\right]^{4+}$ product ion. (c) $\mathrm{CID}-\mathrm{MS}^{3}$ of the $\left[18-42^{30,38}+2 \mathrm{H}-2 \mathrm{~S}\left(\mathrm{CH}_{3}\right)_{2}\right]^{4+}$ product ion. A superscript dagger $\left({ }^{+}\right)$indicates sequence ions containing one modified amino acid residue. A superscript double dagger $\left(^{\ddagger}\right)$ indicates sequence ions containing two modified amino acid residues. A dashed line indicates an unmodified sequence ion was observed. A single solid line indicates a sequence ion was observed with one modified amino acid. A double solid line indicates a sequence ion was observed with two modified amino acids.

difference in the Glu-C enzyme cleavage activity caused by the modification (i.e., the incorporation of the fixed charge may enhance enzymatic cleavage at the cleavable site closest to the modification). The predicted solvent accessibilities of the $\mathrm{P}_{1}$ and $\mathrm{K}_{8}$ residues are $57.8 \%$ and $45.7 \%$, respectively. However, for both the 1-13 and 1-17 peptides, the abundance of the $\mathrm{K}_{8}$ modified peak (e.g., $\left[1-13^{8}\right]$ in Figure 1 was higher than that of the $\mathrm{P}_{1}$ modified peak (e.g., [1-13 ${ }^{1}$ in Figure 1]). This is rationalized as being due to differences in the rate of reactivity between the primary $\varepsilon$-amino group of the lysine side chain and the secondary amine functional group of the $\mathrm{N}$-terminal proline residue, respectively, toward the NHS ester of the DMBNHS reagent.

Both peptides 97-112 and 18-42 contain three lysine residues. The triply modified $18-42$ peptide was observed with a maximum relative abundance of $57 \% \pm$ $5 \%$, while the triply modified $97-112$ peptide was observed with a maximum relative abundance of only $28 \% \pm 1 \%$ (compare Figure $6 \mathrm{e}$ and $\mathrm{f}$, respectively). This overall greater extent of reaction of the 18-42 peptide compared with the 97-112 peptide is consistent with the higher summed predicted solvent accessibilities of the $\mathrm{K}_{20}(49.3 \%), \mathrm{K}_{30}(58.1 \%)$ and $\mathrm{K}_{38}(93.1 \%)$ residues (summed total of $200.5 \%$ ) versus the $\mathrm{K}_{98}(49.6 \%), \mathrm{K}_{101}$ $(72.7 \%)$ and $\mathrm{K}_{106}(42.6 \%)$ residues (summed total of $164.9 \%)$. Also consistent with the predicted solvent accessibilities, which suggest that $K_{38}$ is the most exposed residue followed by $K_{30}$ and finally $K_{20}$, the intensity of the $18-42^{38}$ modified peptide was found to be more abundant than the $18-42^{30}$ modified peptide. Finally, the lack of a singly modified $18-42^{20}$ peak corresponding to modification at the $\mathrm{K}_{20}$ residue is consistent with its significantly lower predicted solvent accessibility compared with the $K_{30}$ and $K_{38}$ residues. Unfortunately, the isomeric singly and doubly modified forms of the 97-112 peptide were not chromatographically resolved. As a result, the predicted solvent accessibilities of each lysine residue could not be correlated with their reactivity. Similarly, the singly, doubly, triply 


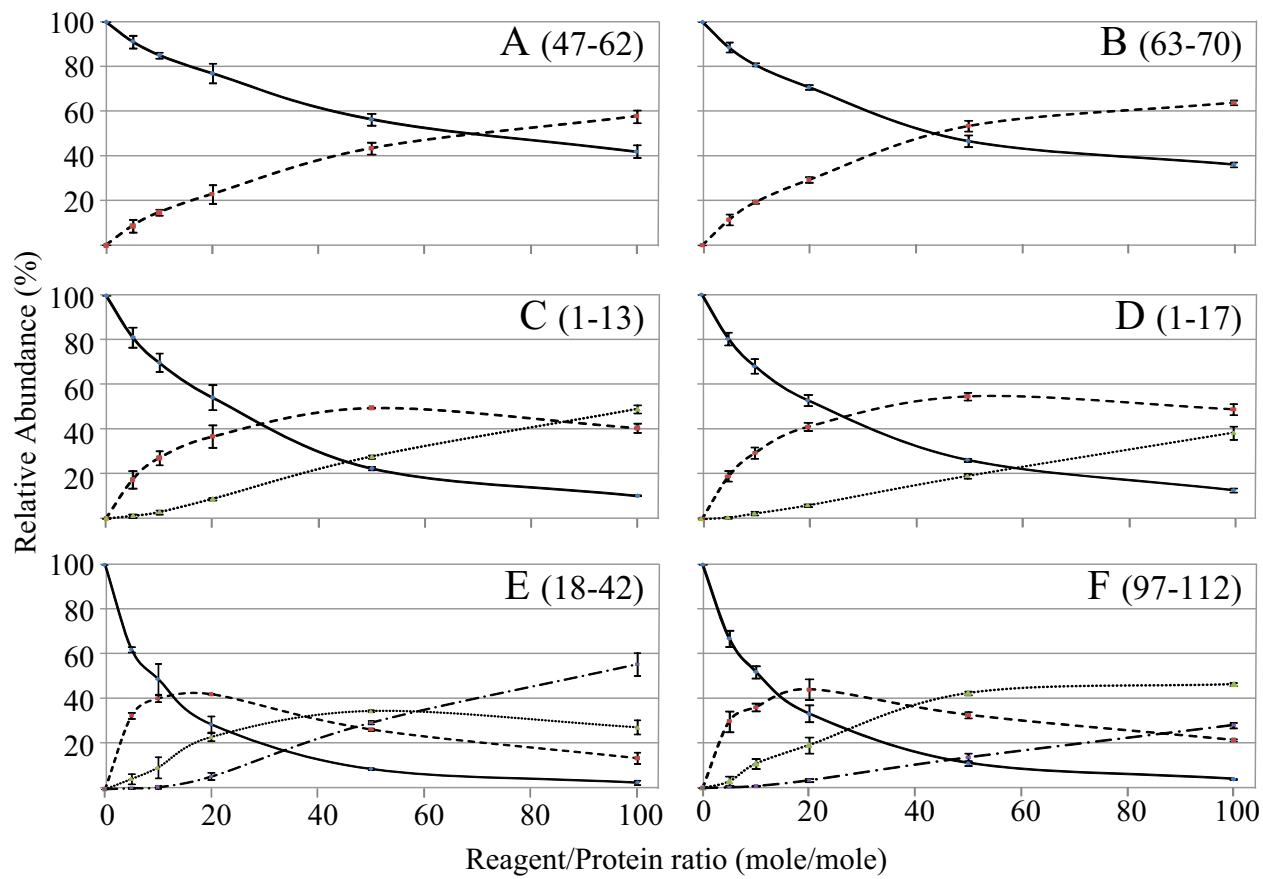

Figure 6. Plots of the relative abundances of unmodified peptides (solid line), singly modified peptides (dashed line), doubly modified peptides (dotted line), and triply modified peptides (dashed and dotted line) versus the molar ratios of reagent over protein. (a) peptide 47-62, (b) peptide 63-70, (c) peptide 1-13, (d) peptide 1-17, (e) peptide 18-42, and (f) peptide 97-112. Samples were separately prepared and run in triplicate. Error bars are shown as \pm SD.

and quadruply modified forms of the 63-96 peptide containing four modifiable sites $\left(\mathrm{K}_{66}, \mathrm{~K}_{82}, \mathrm{~K}_{86}\right.$, and $\left.\mathrm{K}_{92}\right)$ were not chromatographically resolved, precluding the ability to correlate their individual reactivity and predicted solvent accessibility. Overall however, the results described above provide strong evidence that the extent of modification of the DMBNHS reagent is correlated with the protein solvent accessibility.

\section{Conclusions}

The results presented herein describe (1) the synthesis of an amine reactive sulfonium ion containing protein modification reagent, DMBNHS, (2) the development of an automated 'targeted' multistage tandem mass spectrometry strategy for the identification and characterization of protein surface accessible residues, and (3) its initial application to a model protein, CRABP II. DMBNHS modified peptides give rise to exclusive neutral loss product ions upon CID-MS/MS, allowing the selective identification of modified peptides and determination of the number of modifications. Subsequent data dependant $\mathrm{MS}^{3}$ of these neutral loss product ions readily enables characterization of the peptide sequence and localization of the modification site(s). Furthermore, the reactivity of individual residues within the modified peptides is correlated with their predicted solvent accessibilities. The initial success of this experimental strategy, i.e., combing protein modification by DMBNHS with data dependant multistage tandem mass spectrom- etry, provides confidence for its application in future studies involving the examination of protein structure in larger proteins, as well as for the study of protein-protein and protein-ligand interactions.

\section{Acknowledgments}

The authors acknowledge support for this work provided by funding from the National Science Foundation (CAREER: CHE0547940).

\section{Appendix A Supplementary Material}

Supplementary material associated with this article may be found in the online version at doi:10.1016/ j.jasms.2010.03.047.

\section{References}

1. Renzone, G.; Salzano, A. M.; Arena, S.; Ambrosio, C. D.; Scaloni, A. Mass Spectrometry-Based Approaches for Structural Studies on Protein Complexes at Low-Resolution. Curr. Proteom. 2007, 4, 1-16.

2. Englander, S. W. Hydrogen Exchange and Mass Spectrometry: A Historical Perspective. J. Am. Soc. Mass Spectrom. 2006, 17, 1481-1489.

3. Wales, T. E.; Engen, J. R. Hydrogen Exchange Mass Spectrometry for the Analysis of Protein Dynamics. Mass Spectrom. Rev. 2006, 25, 158-170.

4. Xu, G.; Chance, M. R. Hydroxyl Radical-Mediated Modification of Proteins as Probes for Structural Proteomics. Chem. Rev. 2007, 107, 3514-3543.

5. Konermann, L.; Stocks, B. B.; Pan, Y.; Tong, X. Mass Spectrometry Combined with Oxidative Labeling for Exploring Protein Structure and Folding. Mass Spectrom. Rev. 2010, in press. DOI: 10.1002/mas.20256. 
6. Mendoza, V. L.; Vachet, R. W. Probing Protein Structure by Amino Acid-Specific Covalent Labeling and Mass Spectrometry. Mass Spectrom. Rev. 2009, 28, 785-815.

7. Kaltashov, I. A.; Bobst, C. E.; Abzalimov, R. R. H/D Exchange and Mass Spectrometry in the Studies of Protein Conformation and Dynamics: Is There a Need for a Top-Down Approach? Anal. Chem. 2009, 81, 7892-7899.

8. Zhang, H. M.; Bou-Assaf, G. M.; Emmett, M. R.; Marshall, A. G. Fast Reversed-Phase Liquid Chromatography to Reduce Back-Exchange and Increase Throughput in H/D Exchange Monitored by FT-ICR Mass Spectrometry. J. Am. Soc. Mass Spectrom. 2009, 20, 520-524.

9. Jørgensen, T. J. D.; Gardsvoll, H.; Ploug, M.; Roepstorff, P. Intramolecular Migration of Amide Hydrogens in Protonated Peptides upon Collisional Activation. J. Am. Chem. Soc. 2005, 127, 2785-2793.

10. Rand, K. D.; Zehl, M.; Jensen, O. N.; Jørgensen, T. J. D. Protein Hydrogen Exchange Measured at Single-Residue Resolution by Electron Transfer Dissociation Mass Spectrometry. Anal. Chem. 2009, 81, 5577-5584.

11. Rand, K. D.; Adams, C. M.; Zubarev, R. A.; Jørgensen, T. J. D. Electron Capture Dissociation Proceeds with a Low Degree of Intramolecular Migration of Peptide Amide Hydrogens. J. Am. Chem. Soc. 2008, 130, 1341-1349.

12. Sinz, A. Chemical Cross-Linking and Mass Spectrometry to Map Three-Dimensional Protein Structures and Protein-Protein Interactions. Mass Spectrom. Rev. 2006, 25, 663-682.

13. Xu, G.; Chance, M. R. Radiolytic Modification and Reactivity of Amino Acid Residues Serving as Structural Probes for Protein Footprinting. Anal. Chem. 2005, 77, 4549-4555.

14. Guan, J. Q.; Vorobiev, S.; Almo, S. C.; Chance, M. R. Mapping the G-Actin Binding Surface of Cofilin Using Synchrotron Protein Footprinting. Biochemistry 2002, 41, 5765-5775.

15. Sharp, J. S.; Sullivan, D. M.; Cavanagh, J.; Tomer, K. B. Measurement of Multisite Oxidation Kinetics Reveals an Active Site Conformational Change in Spo0F as a Result of Protein Oxidation. Biochemistry 2006, 45, 6260-6266.

16. Sharp, J. S.; Tomer, K. B. Effects of Anion Proximity in Peptide Primary Sequence on the Rate and Mechanism of Leucine Oxidation. Anal. Chem. 2006, 78, 4885-4893.

17. Sharp, J. S.; Tomer, K. B. Analysis of the Oxidative Damage-Induced Conformational Changes of Apo- and Holocalmodulin by Dose-Dependent Protein Oxidative Surface Mapping. Biophys. J. 2007, 92, 1682-1692.

18. Suckau, D.; Mak, M.; Przybylski, M. Protein Surface Topology-Probing by Selective Chemical Modification and Mass Spectrometric Peptide Mapping. Proc. Natl. Acad. Sci. U.S.A. 1992, 89, 5630-5634.

19. Jones, S.; Heyningen, P.; Berman, H. M.; Thornton, J. M. Protein-DNA Interactions: a Structural Analysis. J. Mol. Biol. 1999, 287, 877-896.

20. Tsai, C. J.; Lin, S. L.; Wolfson, H. J.; Nussinov, R. Studies of ProteinProtein Interfaces: A Statistical Analysis of the Hydrophobic Effect. Protein Sci. 1997, 6, 53-64.

21. Beardsley, R. L.; Running, W. E.; Reilly, J. P. Probing the Structure of the Caulobacter crescentus Ribosome with Chemical Labeling and Mass Spectrometry. J. Proteome Res. 2006, 5, 2935-2946.

22. Scholten, A.; Visser, N. F. C.; van den Heuvel R. H. H.; Heck, A. J. R. Analysis of Protein-Protein Interaction Surfaces Using a Combination of Efficient Lysine Acetylation and nanoLC-MALDI-MS/MS Applied to the E9:Im9 Bacteriotoxin-Immunity Protein Complex. J. Am. Soc. Mass Spectrom. 2006, 17, 983-994.

23. McKee, C. J.; Kessl, J. J.; Norris, J. O.; Shkriabai, N.; Kvaratskhelia, M. Mass Spectrometry-Based Footprinting of Protein-Protein Interactions. Methods 2009, 47, 304-307.

24. Shell, S. M.; Hess, S.; Kvaratskhelia, M.; Zou, Y. Mass Spectrometric Identification of Lysines Involved in the Interaction of Human Replication Protein A with Single-Stranded DNA. Biochemistry 2005, 44, 971978

25. Novak, P.; Kruppa, G. H.; Young, M. M.; Schoeniger, J. A Top-Down Method for the Determination of Residue-Specific Solvent Accessibility in Proteins. J. Mass Spectrom. 2004, 39, 322-328.

26. Carven, G. J.; Stern, L. J. Probing the Ligand-Induced Conformational Change in HLA-DR1 by Selective Chemical Modification and Mass Spectrometric Mapping. Biochemistry 2005, 44, 13625-13637.

27. Janecki, D. J.; Beardsley, R. L.; Reilly, J. P. Probing Protein Tertiary Structure with Amidination. Anal. Chem. 2005, 77, 7274-7281.
28. Reid, G. E.; Roberts, K. D.; Simpson, R. J.; O'Hair, R. A. J. Selective Identification and Quantitative Analysis of Methionine Containing Peptides by Charge Derivatization and Tandem Mass Spectrometry. J. Am. Soc. Mass Spectrom. 2005, 16, 1131-1150.

29. Amunugama, M.; Roberts, K. D.; Reid, G. E. Mechanisms for the Selective Gas-Phase Fragmentation Reactions of Methionine Side Chain Fixed Charge Sulfonium Ion Containing Peptides. J. Am. Soc. Mass Spectrom. 2006, 17, 1631-1642.

30. Sierakowski, J.; Amunugama, M.; Roberts, K. D.; Reid, G. E. Substituent Effects on the Gas-Phase Fragmentation Reactions of Sulfonium Ion Containing Peptides. Rapid Commun. Mass Spectrom. 2007, 21, 1230 1238.

31. Froelich, J. M.; Kaplinghat, S.; Reid, G. E. Automated Neutral Loss and

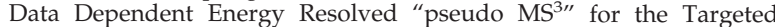
Identification, Characterization and Quantitative Analysis of Methionine-Containing Peptides. Eur. J. Mass Spectrom. 2008, 14, 219-299.

32. Roberts, K. D.; Reid, G. E. Leaving Group Effects on the Selectivity of the Gas-Phase Fragmentation Reactions of Side Chain Fixed-ChargeContaining Peptide Ions. J. Mass Spectrom. 2007, 42, 187-198.

33. Lu, Y.; Tanasova, M.; Borhan, B.; Reid, G. E. Ionic Reagent for Controlling the Gas-Phase Fragmentation Reactions of Cross-Linked Peptides. Anal. Chem. 2008, 80, 9279-9287.

34. Wysocki, V. H.; Tsaprailis, G.; Smith, L. L.; Breci, L. A. Mobile and Localized Protons: A Framework for Understanding Peptide Dissociation. J. Mass Spectrom. 2000, 35, 1399-1406.

35. Dongre, A. R.; Jones, J. L.; Somogyi, A.; Wysocki, V. H. Influence of Peptide Composition, Gas-Phase Basicity, and Chemical Modification on Fragmentation Efficiency: Evidence for the Mobile Proton Model. J. Am. Chem. Soc. 1996, 118, 8365-8374.

36. Cox, K. A.; Gaskell, S. J.; Morris, M.; Whiting, A. Role of the Site of Protonation in the Low-Energy Decompositions of Gas-Phase Peptide Ions. J. Am. Soc. Mass Spectrom. 1996, 7, 522-531.

37. Kapp, E. A.; Schu1tz, F.; Reid, G. E.; Eddes, J. S.; Moritz, R. L.; O’Hair, R. A. J.; Speed, T. P.; Simpson, R. J. Mining a Tandem Mass Spectrometry Database to Determine the Trends and Global Factors Influencing Peptide Fragmentation. Anal. Chem. 2003, 75, 6251-6264.

38. Wang, L.; Li, Y.; Abildgaard, F.; Markley, J. L.; Yan, H. NMR. Solution Structure of Type II Human Cellular Retinoic Acid Binding Protein: Implications for Ligand Binding. Biochemistry 1998, 37, 12727-12736.

39. Williams, K. A; Doi, J. T; Musker, W. K. Neighboring-Group Participation in Organic Redox Reactions. 10. The Kinetic and Mechanistic Effects of Imidazole and Benzimidazole Nitrogen on Thioether Oxidations. J. Org. Chem. 1985, 50, 4-10.

40. Fraczkiewicz, R.; Braun, W. Exact and Efficient Analytical Calculation of the Accessible Surface Areas and Their Gradients for Macromolecules. J. Comput. Chem. 1998, 19, 319-333.

41. Frisch, M. J.; Trucks, G. W.; Schlegel, H. B.; Scuseria, G. E.; Robb, M. A.; Cheeseman, J. R.; Montgomery, Jr., J. A.; Vreven, T.; Kudin, K. N.; Burant, J. C.; Millam, J. M.; Iyengar, S. S.; Tomasi, J.; Barone, V. Mennucci, B.; Cossi, M.; Scalmani, G.; Rega, N.; Petersson, G. A.; Nakatsuji, H.; Hada, M.; Ehara, M.; Toyota, K.; Fukuda, R.; Hasegawa, J.; Ishida, M.; Nakajima, T.; Honda, Y.; Kitao, O.; Nakai, H.; Klene, M.; Li, X.; Knox, J. E.; Hratchian, H. P.; Cross, J. B.; Bakken, V.; Adamo, C.; Jaramillo, J.; Gomperts, R.; Stratmann, R. E.; Yazyev, O.; Austin, A. J.; Cammi, R.; Pomelli, C.; Ochterski, J. W.; Ayala, P. Y.; Morokuma, K.; Voth, G. A.; Salvador, P.; Dannenberg, J. J.; Zakrzewski, V. G.; Dapprich, S.; Daniels, A. D.; Strain, M. C.; Farkas, O.; Malick, D. K.; Rabuck A. D.; Raghavachari, K.; Foresman, J. B.; Ortiz, J. V.; Cui, Q.; Baboul, A. G.; Clifford, S.; Cioslowski, J.; Stefanov, B. B.; Liu, G.; Liashenko, A.; Piskorz, P.; Komaromi, I.; Martin, R. L.; Fox, D. J.; Keith, T.; Al-Laham, M. A.; Peng, C. Y.; Nanayakkara, A.; Challacombe, M.; Gill, P. M. W. Johnson, B.; Chen, W.; Wong, M. W.; Gonzalez, C.; Pople, J. A. Gaussian 03 (Revision B. 04); Gaussian, Inc.: Pittsburgh, PA, 2003.

42. Lioe, H.; O'Hair, R. A. J.; Gronert, S.; Austin, A.; Reid, G. E. Experimental and Theoretical Proton Affinities of Methionine, Methionine Sulfoxide, and their N- and C-Terminal Derivatives. Int. J. Mass Spectrom. 2007, $267,220-232$.

43. Ren, D.; Julka, S.; Inerowicz, H. D.; Regnier, F. E. Enrichment of Cysteine-Containing Peptides from Tryptic Digests Using a Quaternary Amine Tag. Anal. Chem. 2004, 76, 4522-4530. 